\title{
Trends in international investment flows: Foreign direct investment in Mongolia
}

\author{
Baasankhuu Ganzorig and Dashnyam Nachin ${ }^{*}$
}

\begin{abstract}
Despite the worldwide stagnation in FDI, interest in Mongolia on the part of foreign investors, especially those from East Asia, North America, has grown over the last few years, mainly in the mining, trade and service sectors. The increase of FDI into Mongolia can be linked with the Mongolian government's efforts to establish a more favorable external and internal legal environment in order to provide a free and open regime for business, the shifting tendency of world market center from traditional Europe, America to Asia, namely to China, resolving the "big debt" issue between Mongolia and Russian Federation which open new favorable opportunities for intensification of foreign investment inflows, increased domestic private savings and lastly Mongolia's GDP steady growth rate during last years. The purpose of this paper is to review FDI inflows into Mongolia, detailing the sectors benefiting from this investment and the countries where it originates, based on information gathered in the period up to 2005.
\end{abstract}

Keywords: Foreign Direct Investment; Investment flows; Mongolia.

\section{Introduction}

Since the economy was opened in the early 1990s, foreign investment in Mongolia has been increasing steadily, assisted by the amendments to and enforcement of the Foreign Investment Law of Mongolia and various measures taken by the Mongolian government to create a favorable legal environment for foreign direct investment (FDI). There has been worldwide interest in a variety of Mongolia's industrial sectors especially in the mining, trade and service sectors from investors of East

Submission Date: 2/25/2006 Acceptance Date: 11/27/2006

*Foreign Investment and Foreign Trade Agency of Mongolia, Government Bldg. \# 11, Sambuu Street 11, Ulaanbaatar 211238, Mongolia. Tel. (976-11) 326040, Fax: (976-11) 324076, Email: fifta@ investmongolia.com; nachin@investmongolia.com 
Asia, North America and Europe. It has been noted that the liberalization of the investment regime, while making foreign investment procedures simpler, has also given rise to increasing capital flows.

The purpose of this paper is to review FDI inflows into Mongolia, detailing the sectors benefiting from this investment and the countries where it originates, based on information gathered in the period up to 2005 (cumulative data) by the Foreign Investment and Foreign Trade Agency of Mongolia (FIFTA). The Foreign Investment Law of Mongolia provides for a liberal investment regime and protection of investment. This regime allows foreign investors to invest in any sectors, unless specifically prohibited by law, and to establish wholly owned or joint venture companies. The amendments included in the 2002 law relate to the types and forms of foreign investment, and served to further ensure companies could work in a stable business environment. Foreign direct investment (FDI) in Mongolia has been increasing from across the world, particularly from East Asia, North America and Europe, in the mining, trade and service sectors. Promotional activities to attract FDI both at home and abroad and the simplification of foreign investment procedures have been the main contributors to increased FDI.

\section{Foreign direct investment: World trends}

According to the United Nations Conference on Trade and Development (UNCTAD) survey, global FDI inflows rose modestly in 2004, following large declines in their value in $2001(41 \%)$, $2002(13 \%)$ and $2003(12 \%)(U N C T A D, 2005)$. At US\$648 billion in 2004, FDI was 2 percent higher than that in 2003, with 36 percent of FDI occurring in developing countries. The United States was the largest recipient in 2004, ahead of the United Kingdom, China and Luxemburg, which were the top FDI recipients in 2003. The European Union, with its 10 new members, attracted US $\$ 380$ billion, while Japan received US $\$ 8$ billion worth of FDI inflows.

In contrast to developed-country inflows, flows to developing countries rose by 40 percent (to US\$233 billion) in 2004. Flows to Africa remained virtually unchanged (US\$18 billion) in the primary, telecommunication, electric appliances manufacturing and retail trade sectors. FDI flows to Latin America and the Caribbean rose by 44 percent (to US\$68 billion) after four years of consecutive declines. The 50 least developed countries received a total of only US\$11 billion.

In 2004, FDI inflows in Asia and the Pacific increased by US\$46 billion to US\$148 billion compared with 2003. The largest chunk, US\$105 billion occurred in North Asia, while China attracted a record high of US\$61 billion of investment. FDI in flows to South-East Europe and the Commonwealth of Independent States amounted to US\$35 billion, compared with US\$24 billion in 2003. In the Russian Federation FDI inflows grew from US $\$ 8$ billion to US $\$ 12$ billion.

Around 90 percent of World FDI outflows come from developed countries, led by the United States, Great Britain and Luxemburg. FDI outflows by developed countries exceeded their inflows by nearly US $\$ 260$ billion.

Many countries have been progressively liberalizing their FDI regimes, encouraging investments, and concluding both bilateral treaty on mutual protection and encouragement of investment (BITs) and double taxation treaties (DTTs). In 2004, 73 BITs were concluded 
internationally, bringing the total number to 2,392 , while 84 DTTs were signed, bringing total DTTs to 2,559.

\section{FDI inflow into Mongolia up-to and in 2005:}

Under condition of strong international competition for FDI, Mongolia with its small population and market, must pay special attention to the creation of favorable conditions for FDI and private business. The Government of Mongolia passed Law on Foreign Investment in 1990 and subsequently revised the Law in 1993, 1998 and in 2002. The changes have been made with the purpose to create a more favorable investment climate, to improve the legal conditions for potential long-term investors and to bring Mongolian FDI legal environment close to the international standards.

FDI is protected by the Constitution of Mongolia and the Foreign Investment Law complemented by relevant legislation and regulations, as well as international treaties and agreements to which Mongolia is bound. The existing Foreign Investment Law guarantees rights and privileges for foreign investors such that it is prohibited to nationalize and illegally confiscate assets and capital of foreign investors. Foreign investors receive treatment equal to that enjoyed by domestic investors as regards to right to own, utilize, and exploit assets and capital.

The Mongolian government has paid significant attention to FDI and created a more favorable external and internal legal environment, in order to provide a free and open regime for business. : For examples, incentives such as tax exemptions and deductions and policies aimed at encouraging exports have been put in place under taxation and other related laws. This lead to an increase in the total amount of FDI as well as in the breadth of the sectors. In 2001 the Government of Mongolia through the new Special Licensing Law has reduced the number of licenses and permissions that needed to be obtained for business activities from 600 to 87 . Also as a trade facilitation measure, Ecustoms system has been implemented by the General Taxation Office of Mongolia.

Since 1991 Mongolia has concluded DTTs with 33 countries and BITs with 39 countries. Trade agreements concluded by the Government of Mongolia, especially those with the U.S. and EU, which gave to Mongolia the status of the Most Favorable Nation, played a big role in attracting FDI to Mongolia. Mongolia acceded to the "Washington Convention on Investment Dispute Settlement of 1965" in 1996, joined the World Trade Organization in 1997, and joined the "Seoul Convention on Investment Insurance of 1985" in 1999. Mongolia is a full member of the Multilateral Investment Guarantee Agency (MIGA) of the World Bank Group and investors are, therefore, eligible for risk insurance through MIGA. Those international treaties and agreements provide for most-favored and national treatment legal guarantees in respect to the rights of the investors.

In recent years, Mongolia's GDP growth rate has been steadily increasing, reaching 6.2 percent in 2005 (Table 1). This continued economic growth was the main factor that led donor countries to consider Mongolia as a country shifting from the transition phase to the growth phase at the consultative meeting of Mongolia's donor countries held in Tokyo in November 2003 (ADB, 2003). 
Table 1

GDP growth

\begin{tabular}{c|c|c|c|c|c|c}
\hline & 2000 & 2001 & 2002 & 2003 & 2004 & 2005 \\
\hline GDP growth (\%) & 1.1 & 1.0 & 4.0 & 5.5 & 10.6 & 6.2 \\
\hline
\end{tabular}

As a result of policy measures taken by the Government of Mongolia to establish a more favorable environment, the total amount of FDI has increased significantly. In 1995-1996 around US\$30-40 million of FDI was registered annually. In recent years, however, FDI inflows has increased to more than US\$200 million each year: FDI was US\$237 in 2004 and US\$311 million in 2005. The total cumulative FDI inflows registered US $\$ 1.44$ billion by 4,800 foreign companies from 88 countries since 1990. Around 80 percent of total FDI was undertaken in the period 20002005. Some of these FDI inflows comprises re-investments by existing investors, which confirms the reliable investment conditions and business environment in the country. More than 40 percent of foreign investment was in the mining and geological prospecting sectors.

\subsection{Sectors and originating countries of FDI inflows up-to 2005}

A trend of FDI inflow from 1990 to 2005 is shown in Fig. 1. A summary of FDI inflows by sectors and a summary of top 10 investor countries are also shown in Table 2 and Table 3 respectively. Fig. 1. indeed shows a phenomenal rise of FDI inflows during this period.

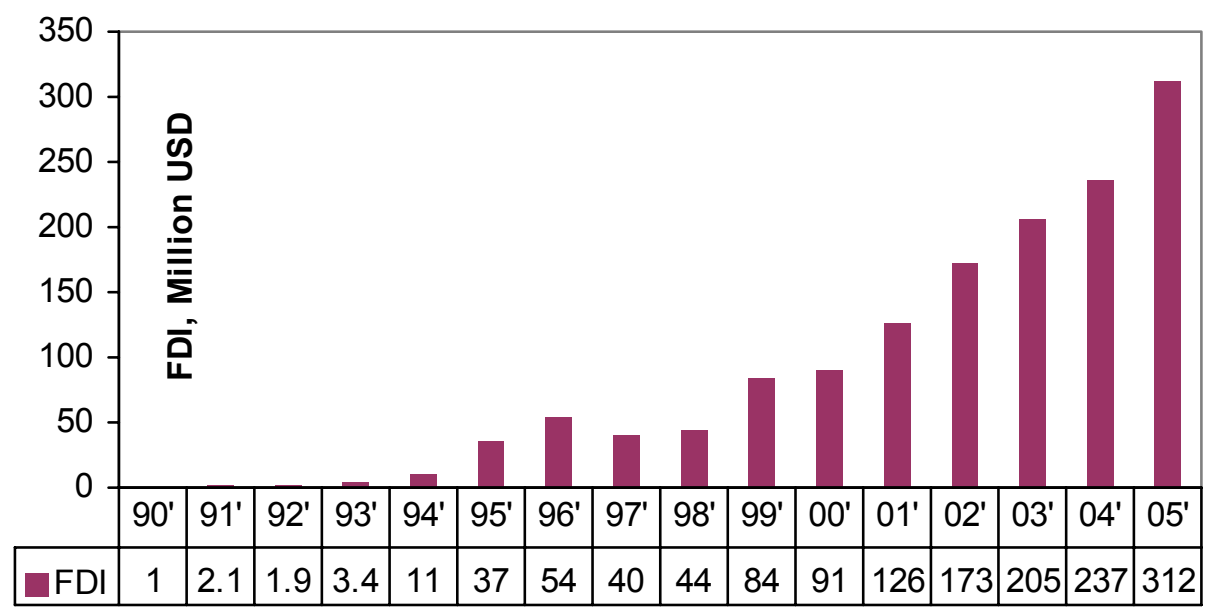

Fig. 1. FDI Inflow by years (\$US) 
As is shown in Table 2, FDI in the mining and minerals sector now represents about half of total FDI, while trade and catering compromises 15.4 percent, light industry 6 percent, banking and financial services 5.3 percent, construction 3.9 percent, and processing of animal originated raw materials 3.8 percent.

In 2005 FDI in the geological prospecting, oil exploration and mining sector amounted to US\$191 million, compared to US\$60 million in 2001. Following active FDI in this sector many new business activities were created in Mongolia.

The construction sector is on the rise, primarily due to the implementation of The Land Ownership Law of Mongolia, which allows for private ownership of land. The Program on 40 thousand houses has also had a positive impact on the construction sector.

FDI in the banking and financial services sector increased to above 5 percent of total FDI in 2005. The highest FDI flow - US\$ 19.7 million - occurred in 2001. Since then banking has been an important sector for FDI because of the privatization of The Trade and Development Bank and the Agricultural Bank of Mongolia, and further liberalization in the banking system.

In the 2000-2005 period, FDI flows into the tourism sector increased to US\$5.6 million. Today, FDI in the tourism sector comprises around 1.1 percent of total FDI and 10 percent of the country's GDP.

There has, however, been declining FDI in the textile and garment sector due to expiration of the WTO multilateral fiber agreement, and China becoming a member of WTO.

Table 2

Summary of FDI inflow in Mongolia by sectors up-to 2005

\begin{tabular}{l|c|c}
\multicolumn{1}{c}{ Sector } & Total & $\%$ \\
\hline \hline Geological prospecting, mining and oil exploration & 686,820 & 47.7 \\
Trade and catering service & 221,282 & 15.4 \\
Light industry & 86,846 & 6.0 \\
Banking and financial services & 76,807 & 5.3 \\
Engineering construction and production of building materials & 56,118 & 3.9 \\
Processing of animal originated raw materials & 54,673 & 3.8 \\
Telecommunication & 25,928 & 1.8 \\
Transportation & 21,425 & 1.5 \\
Production of food and beverages & 15,614 & 1.1 \\
Tourism & 14,738 & 1.0 \\
Others & 180,724 & 12.5 \\
Total & $1,440,975$ & 100.0 \\
\hline
\end{tabular}

The principal sources or top 10 investor countries of FDI are summarised in Table 3. Let us now briefly review the characteristics of FDI from the major countries among these. 
Table 3

Top 10 investor-countries (cumulative value in thousand US\$)

\begin{tabular}{|c|c|c|}
\hline Country & Total & $\%$ \\
\hline China & 682,766 & 47.4 \\
\hline Canada & 175,736 & 12.2 \\
\hline Republic of Korea & 104,588 & 7.3 \\
\hline Japan & 71,346 & 5.0 \\
\hline British Virgin islands & 51,915 & 3.6 \\
\hline USA & 51,217 & 3.6 \\
\hline Russia & 45,944 & 3.2 \\
\hline UK & 32,429 & 2.3 \\
\hline Bulgaria & 30,778 & 2.1 \\
\hline Hong Kong (China) & 25,818 & 1.8 \\
\hline Other Countries & 168,439 & 11.7 \\
\hline Total & $1,440,975$ & 100.0 \\
\hline
\end{tabular}

\section{People's Republic of China}

China is currently the leading investor as measured by both the amount of investment and number of companies. Chinese FDI growth is noted in such sectors as geology-mining (US\$ 360 million), trade and catering services (US\$ 151 million), engineering construction and construction materials (US\$ 29 million), and light industry (US\$ 23 million).

\section{Canada}

Canadian investors have been very active in the mining and minerals sector but, in 2005, registered only US\$ 1.5 million FDI.

\section{The Republic of Korea}

Every year the amount of FDI from the Republic of Korea is increasing, taking place in various industrial and service sectors (geology-mining US\$ 15 million, light industry US\$ 6.7 million, transportation \$US5.7 million, and engineering construction and construction materials US\$ 4.6 million).

\section{Japan}

Japanese investors, comprising 225 companies, invested US\$ 71 million in the following sectors: light industry (US\$ 28.1 million which is $32.4 \%$ of sectoral FDI), telecommunications (US\$ 8.6 million - the highest in the sector). The Mongolia-Japanese Buyan holding and Sanshiroh JVCs' contributions to FDI into light industry are significant. In 2005 Japanese investors invested US\$ 5.4 million in Mongolia. 


\section{United States}

Investors from the US were more focused on geology-mining and oil (US\$ 21 million), processing of animal origin raw materials (US\$ 7 million), light industry (US\$ 4.6million), banking and financial services (US\$ 4.6 million), and construction and construction materials (US\$ 2.6 million).

\section{The Russian Federation}

FDI flows from Russia tended to be in such sectors as geology-mining (US\$ 17 million), construction and construction materials (US\$ 5.3 million), banking and financial services (US\$ 4.1 million), and the food industry (US\$ 4.1 million).

\section{European Union}

Investors from Great Britain, Italy, Germany and Czech Republic have a leading position from this group. Majority of investment from the EU were made in an area of processing of animal originated raw materials, banking and financial services, production of foods and beverages, geological prospecting and exploration sector and other sectors. In 2005 FDI flows from Great Britain and Italy increased by US\$ 6.6 million and US\$ 5.2 million, respectively.

\subsection{Ownership and average value of investment}

Among the 4,814 foreign incorporated companies, 75.9 percent represent individual ownership, with the remaining 24.1 percent comprising larger companies. The average amount of FDI per company for all industries, is about US\$293,000. However, this figure jumps to around US\$2.3 million in the case of the geology-mining and oil sector.

\subsection{FDI bylocation}

Almost all FDI, 95\% of total FDI occurred in the capital city of Ulaanbaatar, with only 5 percent (i.e. about US\$ 72.6 million) in the provinces. Amongst the provinces $7.5 \%$ of FDI occurred in the Western region, $34.6 \%$ in the Khangai region, $41.1 \%$ in the Central region and $16.7 \%$ in the Eastern region. FDI is, therefore, concentrated - not unexpectedly - in those locations typified by more developed infrastructure. 


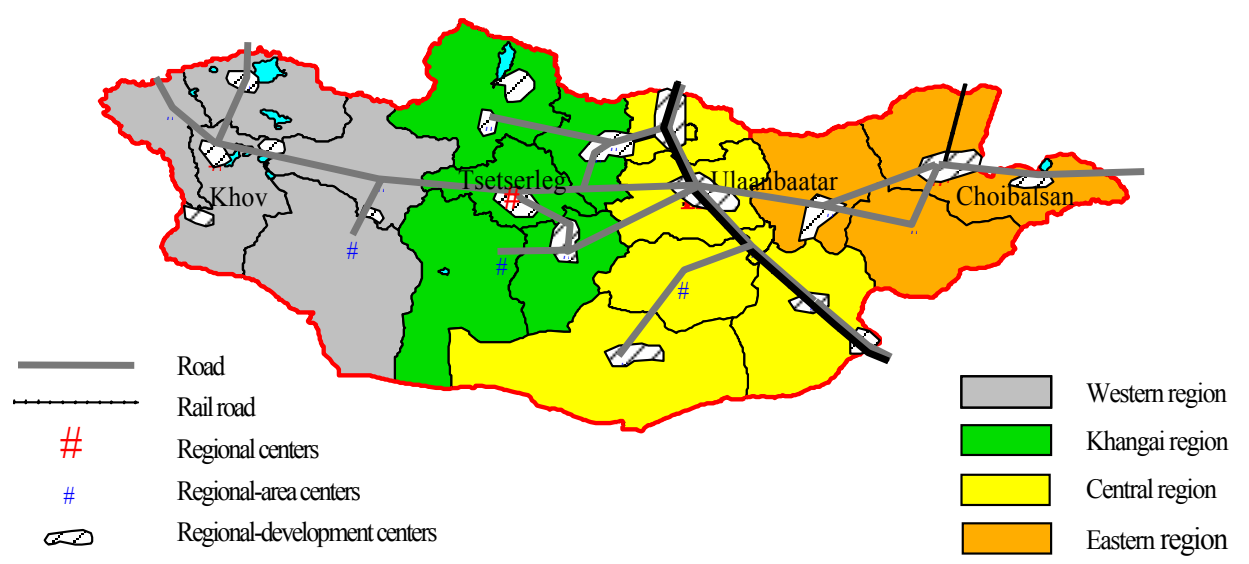

Fig. 2. Regional economic development in Mongolia

Western Region (Zavhan, Uvs, Khovd, Bayan-Olgii, Gobi-Altai provinces)

Since 1993 total direct investment of US\$ 5.5 million for activities including geology-mining, food processing, light industry and service sectors has occurred.

Khangai Region (Khovsgol, Bulgan, Orkhon, Arkhangai, Ovorkhangai, Bayankhongor provinces)

According to FIFTA records, since 1992 total direct investment of US\$ 25.1 million has been registered in this region in the mining, wool, leather and wood processing industries, construction, tourism, agriculture and services sectors.

Central Region (Selenge, Darkhan Uul, Tov, Dundgovi, Dornogovi, Gobisumber, Omnogovi provinces)

Since 1992 total investment of US\$ 29.8 million has occurred, mainly in the geology-mining, light industry, manufacturing, building materials and services sectors.

Eastern Region (Khentii, Dornod, Sukhbaatar provinces)

Since 1992 total foreign investment of US\$12.1 million has occurred, mainly in the geologymining and agriculture sectors.

\section{Free Economic Zones}

The Parliament of Mongolia recently passed a number of laws for the development of free economic zones in the period 2002-2004 (Free Trade Zone Law, Altanbulag Free Trade Zone Law, Zamiin-Uud Free Economic Zone Law and Tsagaan Nuur Free Trade Zone Law). The tenders for Altanbulag Free Trade Zone and The Zamyn Uud Free Economic Zone have been announced. 


\section{Other economic aspects of FDI}

As a result of measures taken by the Mongolian government, the amount of FDI has increased, bringing new investment from a diversified and growing group of international investors into numerous sectors, both new and old. This has helped to broaden the economic base of the country's economy, while providing more opportunities for the workforce.

To date, foreign companies have created around 80,000 jobs. They account for around half of the country's total exports and 60 billion Mongolian togrogs of tax revenue, which is more than 10 percent of the total tax revenue in recent years. According to the General Taxation Authority, in 2005 foreign companies paid 81 billion togrogs in tax, which is $35 \%$ higher than in the previous year. Besides creating new job opportunities and paying taxes, foreign companies are promoting other industrial and service sectors.

In 2005, GDP growth reached 6.2\%, and total external trade turnover increased by $16.5 \%$ to US\$ 2.2 billion. Exports of US\$ 1,053.7 million represented an increase of $21.2 \%$. The external trade balance decreased by $37 \%$ compared with 2004 .

\section{FDI in 2005 and outlook beyond}

In 2005, there was a total number of 988 foreign companies registered, with investments of US\$ 311 million in that year. Compared to 2004, these indicators rose by $27 \%$ and $31 \%$, respectively.

Table 4

FDI inflow by major sectors in 2005

\begin{tabular}{c|l|c}
\hline № & \multicolumn{1}{|c|}{ Sectors } & $\begin{array}{c}\text { Investment } \\
\text { (in thousand US\$) }\end{array}$ \\
\hline \hline 1 & Geological prospecting, oil exploration \& mining & 191,071 \\
2 & Trade and catering service & 53,930 \\
3 & Banking and financial services & 9,671 \\
4 & Telecommunication & 6,268 \\
5 & Agriculture & 2,797 \\
6 & Light industry & 1,840 \\
7 & Tourism & 1,665 \\
8 & Community household service & 1,354 \\
9 & Processing of animal originated raw materials & 1,125 \\
10 & Engineering construction and production of & 775 \\
\hline
\end{tabular}




\begin{tabular}{l|l|c}
\hline 11 & Transportation & 434 \\
12 & Production of foods and beverages & 294 \\
13 & Houseware production & 194 \\
14 & Energy & 100 \\
15 & Health and beauty services & 56 \\
16 & Electric appliances manufacturing & 31 \\
17 & Furniture production & 22 \\
18 & Culture, education, science and press & 13 \\
19 & Jewelry and gifts & 40,119 \\
20 & Others & 311,746 \\
\hline
\end{tabular}

A recent, positive factor for increasing FDI flows into Mongolia is the shifting focus of world market centers from Europe and America to Asia, particularly to China. Since joining the World Trade Organization (WTO), China has agreed to decrease import tariffs on industrial goods and products from an average of 24.6 percent to an average of 9.4 percent, and to lower import tariffs on agricultural products from 31.5 percent to 17.4 percent. It is expected, therefore, that there will be increased interest from foreign investors to invest in Mongolia because of its liberal economic policy and investment regime, and its proximity to China. Consequently, the government of Mongolia is increasing its efforts to forge sound relations, along with increased trade and economic cooperation, with both China and Russia.

In addition, the "big debt" issue between Mongolia and the Russian Federation was successfully resolved at the end of 2003, thereby opening new, favorable opportunities for the intensification of foreign investment inflows to Mongolia. In 2005, the Moody's and Fitch Ratings agencies have assigned a long-term foreign currency and local currency rating of $\mathrm{B}+$ to Mongolia. At the same time, the agency assigned the country a short-term rating of B and a country ceiling rating of $\mathrm{B}+$. The outlook on the ratings is stable. Fitch's rating action reflects Mongolia's marketfriendly environment, healthy international liquidity position, normalized relations with external creditors and low external debt service burden, weighted against a high government debt burden and ongoing development challenges.

The EU has approved the rule of tariff preference for 2006-2008 on 27 June, 2005. Through this new rule, the EU made new preferential treatment of "GSP+" 7,200 item. For instance, all types of commodities such as textiles and knitted products, skin and hides, wool and cashmere, beverages, spirits, wooden items, electronic goods, shoes, carpets, copper and copper products, iron and iron products, just to name a few are exempted from custom tariffs for a country with a small economy that indicates "good governance, sustainable development." Mongolia, with other 13 countries, is covered by the new GSP + . It is obvious that not only domestic enterprises but also foreign invested companies will benefit, and with no doubt their numbers will also grow.

As was indicated in a WTO secretariat report on the trade policies and practices of Mongolia, early market-oriented reforms, including establishment of an open trade regime, significantly 
helped the transition of Mongolia from a centrally planned economy until 1991 to a market-based economy. This also may be an important factor for Mongolia to currently enjoy stable economic growth and moderate inflation(WTO, 2005).

Lastly, according to "Doing Business 2007" by the World Bank and the International Finance Corporation, Mongolia is the $45^{\text {th }}$ favorable place out of 175 countries covered by the survey on business environment. All of these show an improved external environment favorable to attract FDI into Mongolia.

In the framework of the Government of Mongolia's measures to align the tax system with country competitiveness by reducing the tax rates and burden on businesses to enable job creation and induce a reduction of the informal economy, in June, 2006 the Parliament of Mongolia passed the new edition ${ }^{1}$ of laws on corporate income tax, personal income tax, value added tax and excise tax, which will be in force beginning from January 1, 2007. The new set of laws removes discriminatory provisions against domestic investors and gets rid of a large number of distorted VAT exemptions and provisions. The increase in private savings ( 86.4 billion Mongolian togrog in 1998 to 497.8 billion in 2004) showed a significantly improved banking system. In addition to the impact privatization of the Trade and Development Bank and the Agricultural Bank of Mongolia, it may also have a positive impact on attracting foreign investment to the banking and financial sector.

In recent years, Mongolia's GDP growth rate has been steadily increasing, and estimated to be around $7.5-8.0 \%$ in 2006. This economic growth performance was the main factor for Mongolia to

\footnotetext{
${ }^{1}$ The new Corporate Income Tax Law reduces the lower tax rate from $15 \%$ to $10 \%$, and the higher rate from $30 \%$ to $25 \%$ raises the threshold for the higher rate from 100 million MNT to 3 billion MNT; thus, $99 \%$ of corporate taxpayers will effectively operate in a "flat tax environment". Besides, the new Corporate Income Tax law permits business entities to deduct more of their legitimate business expenditures provides for an investment tax credit, encouraging business investment, provides for loss carry-forward, supporting new and temporarily troubled business entities, eliminates most discriminatory tax exemptions and holidays, leveling the playing field for foreign and domestic investors and brings the law closer to international best practices.

The new Personal Income Tax Law unifies the tax rate on taxable personal income at 10 percent, replacing the existing three-tiered rate of 10,20, and 30 percent; raises the tax credit on taxable personal income from MNT 48,000 a year to MNT 84,000, statutorily exempting from taxes those below the poverty line, around 30 percent of the population, as well as at least an additional one-third of low-income citizens.

The new Value Added Tax Law reduces the VAT rate from 15\% to $10 \%$ and eliminates the majority of the exemptions, removing distortions. VAT exempted on imported technique, equipment, materials, raw materials, spare parts, gasoline and diesel fuel in connection with petroleum activity which made contract with Government on production sharing agreement. VAT exempted also on gas fuel, its container, special purposes equipment, machinery and accessories. The list of these goods will be approved by the Government.

The New Excise Tax Law imposes a monthly tax on gaming devices, changes the methodology for tax imposed on imported vehicles and increases the tax amount, discouraging importation of older, more-polluting vehicles and increases the rates on most alcohol products.

Mongolia applies a flat rate of 5\% import duty. Purebred live animals, some information technology and medical and veterinary equipment, their spare parts are duty free. Wheat flour, vegetables have seasonal tariff rates.

Mongolia applies a limited number of export duties on selected raw materials such as cashmere, camel wool, goat skin, timber, ferrous and aluminum waste and scrap,
} 
implement its National Development Strategy till 2015. However, as was there still is a need of US\$ 10 billion FDI and US\$ 2 billion ODA(Bayartsaikhan, 2006). However, as was mentioned by the Finance Minister of Mongolia at the Second Technical Meeting of Government of MongoliaExternal Partners.

Based on the FDI trends in Mongolia up-to and in 2005 and increased investors' interests, it is expected that investment will be around US\$500 million to US\$ 1billion in 2006-2008. Investment will most likely to continue in the areas such as geological prospecting and mining recently emphasized by foreign investors such as Rio Tinto, Mitsui and others. Investments made by International Financial Corporation into the Agricultural Bank and the Trade and Development Bank can justify this increased FDI trend as well. Increased FDI trend in the tourism sector is also expected based on the recently signed agreement to build famous Asian five star hotel chains in Ulaanbaatar, Mongolia.

In addition to the above issues, attraction of FDI into the Free Economic zones and Regional Economic Development zones will remain as the highest priority within the strategic plan for FIFTA $^{2}$ and there is an estimation to get solid investments in 2007-2008. Joint collaborative works with counter partners on the establishment of an industrial park for processing skins and hides are underway.

The continued growth in FDI in Mongolia over the past decade is reflected in the UNCTAD's surveys. UNCTAD's inward FDI performance index ranks countries by the FDI they receive relative to their economic size, calculated as the ratio of the country's share in global FDI inflows to its share in global GDP. Reference to the Index, which covers 140 countries, indicates that Mongolia's ranking has risen from $82^{\text {nd }}$ place in $1995-1997$, to $73^{\text {rd }}$ in $1997-1999,62^{\text {nd }}$ in 1998 $2000,45^{\text {th }}$ in $1999-2001,28^{\text {th }}$ in $2000-2002$, and finally to $15^{\text {th }}$ in $2001-2003$.

UNCTAD's 1999-2001 Inward FDI Potential Index, measuring the potential - based on a set of structural variables - of countries to attract FDI, also shows that Mongolia's ranking has risen from $95^{\text {th }}$ place in $1993-1997$ to $69^{\text {th }}$ in $1996-1997$, and to $63^{\text {rd }}$ in 2001-2003. Many industrial, newly industrializing and advanced transition economies are in the front-runner category (with

\footnotetext{
${ }^{2}$ According to the provision 2.2, Article 14 of Foreign Investment law of Mongolia which made by amendment in 2002 Foreign Investment and Foreign Trade Agency of Mongolia (FIFTA) has a right ...to research possibilities to increase foreign investment, to organize investment promotional activities, to provide investors with relevant information....and running activities to attract and promote foreign direct investment into the key social and economic sectors of the country. FIFTA provides investment matchmaking services to both foreign and Mongolian investors, hosts foreign-investors' missions and organizes Mongolian business missions overseas, as well as international investors conferences and seminars.

FIFTA's One Stop Service Center is designed to coordinate assistance to investors wishing to establish business enterprises, by providing a local network facility that will enable investors to comply with all registration procedures. At this center investors can benefit from the professional advice and support of the representatives of important government authorities such as tax, customs, labor and other business licensing organizations. Its registration service is directed to issue a certificate of incorporation with foreign investment or representative offices based on investor's application; and its aftercare service concentrates on assistance to investors in facilitating further stages of the investment process and running the business including supporting import of capital and equipment, issuing ID card for investor's residency permission and multiple entry visas to Mongolia, as well as assisting with guidance on problems faced by investors at the relevant authority level. See www.investmongolia.com
} 
high FDI potential and performance), while most poor (or unstable) economies are in the underperformer category (with both low FDI potential and performance). In the 1993-1995 period Mongolia was in the lowest FDI potential and performance category, but in 1999-2001 and 20012003 it had moved to the front-runner, high potential FDI category.

\section{Conclusion}

The Mongolian government has been successful in developing and implementing policies aimed at opening up the country, attracting FDI, and building a favorable legal environment in line with global standards. As a result, FDI flows into Mongolia has increased reaching cumulative value of US\$ 1.4 billion in 2005. More significantly Mongolia has great potential for more FDI and economic growth in the future.

It is imperative, therefore, to use this internationally recognized comparative advantage for attracting FDI into key domestic development sectors such as mining, tourism and agro-processing. It is important to transfer and adapt innovative technologies in order to increase the competitiveness of local products and services, and programs targeted at investors concerning the re-investment of profits, the protection of the environment and consumer rights. Especially since the improved competitiveness is closely related to the transfer of innovative technology, efforts should be made to use FDI for this purpose.

\section{References}

The Asian Development Bank (ADB). 2003. Report on the tenth consultative group meeting on Mongolia, Tokyo, November 19-21. ADB.

Bayartsaikhan N. 2006. Minister for Finance of Mongolia, Speech at the Second Technical Meeting of External Partners-Government of Mongolia, Ulaanbaatar Hotel, Mongolia, October 9-10.

EU. 2005. The provision of EU Council on implementing general system of tariff preference (№ 980/2005)

Government of Mongolia (GOM), 2001, State Information 2001, \#34, Government Resolution \# 140 on Approving a List of Priority Sectors for Foreign Investment.

Government of Mongolia (GOM), 2002, State Information 2002, \#5, Amendment to the Foreign Investment Law of Mongolia.

Government of Mongolia (GOM), 2005a, State Information 2005, \#11, Government Resolution \# 32 on Some measures for providing stable manufacturing activities of knitting and garment goodst. 
Government of Mongolia (GOM), 2005b, State Information 2005, \#32, Government Resolution \# 144 on Approving the 40.000 housing unit National Program.

Foreign Investment and Foreign Trade Agency (FIFTA) 2004, 2005, 2006, FDI Review 20022003, 2004, 2005. Ulaanbaatar, Mongolia: FIFTA.

National Statistical Office of Mongolia (NSO), 2000-2006, Statistical Bulletin of Mongolia 20012005, Ulaanbaatar: NSO.

Tsogtbaatar D. 2004. Speech by foreign policy advisor to the Mongolian president at the meeting of businessmen from Mongolia and Turkey held in the city of Izmir, Turkey, May 1, 2004. www.extmin.mn/medee040501.html

United Nations Conference on Trade and Development. 2002. World investment report 2002: Transnational corporations and export competitiveness. New York and Geneva: United Nations.

United Nations Conference on Trade and Development. 2003. World investment report 2003: FDI policies for development: National and international perspectives, New York and Geneva: United Nations.

United Nations Conference on Trade and Development. 2004. World investment report 2004: The shift towards services, New York and Geneva: United Nations.

United Nations Conference on Trade and Development. 2005. World investment report 2005: Transnational corporations and the internationalization of R\&D, New York and Geneva: United Nations

The WTO Report. 2005. TRADE POLICY REVIEW: MONGOLIA, Early market-oriented reforms helped the transition to a stable economic growth. http://www.wto.org/english/tratop_e/tpr_e/tp245_e.htm

Zuuny medee newspaper, \# 267, November 9, 2006 edition, Full text of new editions of laws: Corporate Tax Law, Personal Income Tax Law, Value Added Tax Law and Excise Tax Law of Mongolia (in Mongolian). 